\title{
XXIII. History of astronomy for the year 1801
}

\section{Jerome Lalande}

To cite this article: Jerome Lalande (1802) XXIII. History of astronomy for the year 1801, Philosophical Magazine Series 1, 12:46, 112-121, DOI: $10.1080 / 14786440208676037$

To link to this article: http://dx.doi.org/10.1080/14786440208676037

$$
\text { 曲 Published online: } 18 \text { May } 2009 .
$$

Submit your article to this journal 준

LII Article views: 2

Q View related articles $\asymp$ 
fraction of prifms or of lenses, or by thin plates of air or water between lenses made to approach each other, or by the rings on bubbles, or by reflections or inflections of light, may be explained from the facts contained in the above propofition.

All the experiments, obfervations, and reafoning above, refpect only coloured light. I dare not venture, on theory, to affert any thing as to the exiftence of an elementary, pure, uncoloured, uncompounded white light; yet that fome fuch elementary fubftance exifts, combined with one or more of the principles of our atmofphere, and alfo in combuftible and incombuftible, and perhaps animal and vegetable fubftances, feems to be probable; for it can be feparated from fuch in various operations of nature and art.

However, although light may principally exift, combined with caloric and other fubftances, in a gafeous form, yet it may, and it is very generally admitted, that it does affo exift, independent of caloric, in folid bodies and fluids of various kinds ; and heat, it cannot be denied, exifts fenfibly in both combuftible and incombuftible bodies which exhibit no vifible light. Indeed, that light and heat are two diftinct exifting principles is now finally and demonftrably afcertained and proved by Dr. Herfchel's curious experiments of the fact, thowing that heat as well as light are each liable to different and peculiar refractions, by which they are feparated from each other, and take a feparate and diftinct exiftence in different fpace.

Quod reftat defideratum eft.

XXIII. Hiftory of Afronomy for the Year 1801. By JEROME LALANDE.

$\mathrm{T}$ HE commencement of the I th century was diftinguilhed by an aftronomical event, the difcovery of a planet at Palermo in Sicily, by M. Piazzi, on the $1 \mathrm{ft}$ of January *. It was as finall as a far of the 8th magnitude: he obferved it during forty days. The obfervations he fent me arrived too late for us to be able to follow it, and we were obliged to calculate its orbit from his own oblervations alone. Burckharit, Olbers, Bode, Piazzi, and Gaufs, have found that to reprefent thefe obfervations it is neceffary to fuppofe that

* I here employ the calendar of all nations, being perfuaded that the French government will foon renounce the new calendar, which is not underftood, and cannot be adopted either by our neighbuurs or by the majority of the French themfelves. - L. 
it revolves in four years. The following are the elements found by Burckhardt and Gaufs:

Inclination - - $10^{\prime \prime} 47^{\prime}$ Inclination - $10^{\circ} 3^{6^{\prime}} 57^{\prime \prime}$ Node - - $2^{\mathrm{s}} 20^{\circ} 5^{8}$ Node - $2^{\mathrm{s}} 21044$ Aphelion - 29 O Epoch - - $2^{\mathrm{s}} 16^{\circ} 28^{\prime}$ Paffage of the aphe-

liun Jan. I, I801 8 hours

Eccentricity - 0.0364

Semi-axis - 2.574 Mean anom. - 3 r5 55 Aphelion $10^{s} 26^{\circ} 27^{\prime} 3^{8^{\prime \prime}}$ Eccentricity - 0.0825017

Eution - - - 928 Revolution - 4.13 years Diftance - - - 27355

The difference of thefe elements appeared to me to throw fome doubt on the reality of this orbit of four years; but in the beginning of the year 1802 it was perfectly confirmed, and we now have a ninth planet.

On the $25^{\text {th }}$ of October we received a printed memoir of Piazzi, with his obfervations and calculations. As he hopes that this ftar will be acknowledged to be a planet, he has given it the name of Ceres Ferdinandea, in honour of the king of Naples; and Bode withes it to be called Juno: as for my part, I thall call it Piazzi, as I gave the name of Herfchel to the planet difcovered in 1781. The pagan deities are no longer interefting, and adulation pleafes only the perfon who is the object of it.

On the I 2 th of July, in the evening, Meffier, Mechain and Bouvard, each found a fmall comet near the head of the Great Bear; and it appears that it was feen the preceding night by Pons, concierge of the obfervatory at Marleilles. The Board of Longitude has given him the 600 francs which I depofited in the hands of a notary for the perfon who thould difcover a comet; the three able aftronomers of Paris having themfelves judgred that the artilt ought to be encouraged.

John Louis Pons was born at Peyre, a village in the department of the Upper Alps, on the 24th of December $176 \mathrm{I}$, and has refided at the obfervatory of Marfeilles fince the $3^{\mathrm{d}}$ of February 1789 : his conduct, addrefs, and intelligence, have procured him much efteem from the director of the obfervatory. He conftructed the night-telefcope, with which he difcovered the comet of the 1 Ith of July 180r, on the model of a telefcope by George Adams, which is at the School of Navigation, Marfeilles. The Board of Longitude have fent him a better one.

I have had a new proof of the ntility of the fifty thoufand ftars which I have procured to aftronomy, and of the exact pofitions which my nephew Lefrançois has fixed for the ftars formerly obferved. Several of them have ferved to determino the places of the new comet, which Meffier, Mechain and

VOL. XII, No. 46. H

Bouvard 
Bouvard followed with affiduity, and the orbit of which will be very well determined, though it appeared only ten days.

Thulis has fent me feven obfervations, from the 12th to the 2Ift of July, deduced only from the azimuths and altitudes, without having been able to compare them with ftars; but we were more fortunate at Paris, and Mechain bad fufficient data to calculate the elements in the following manner by a firft fketch :

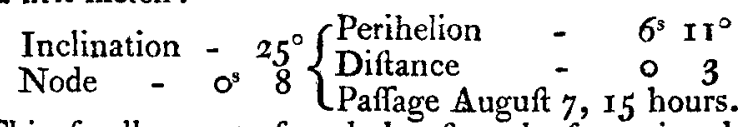

This fmall comet, found almoft at the fame time by four perfons, proves that it is not difficult to difcover comets. Three or four have been feen in the courfe of a year; and if a few amateurs would employ themfelves in fearching for them, it is probable that the number would rapidly increafe. This is ftill a defideratum in aftronomy; it is humiliating for us, that we do not know whether it is by thoufands or tens of thoufands that comets ought to be counted, and whether they return, or lofe themfelves in the immenfity of the univerfe.

Nothing is neceffary but a common telefcope to fearch for and find comets, and to point out their fituation to aftronomers. I fuppofe that the obferver is provided with a wooden quadrant of two feet radius, which any carpenter can make, and that a meridian has been traced out with a large circle on the floor; that the circle is divided into degrees, and that the inftrument is directed towards the place where the comet is. Both the altitude and diftance from the meridian will be thus found for the time of opfervation. Nothing more will be neceffary to enable aftronomers to find a comet which may have been announced. To find comets, it is not necerfary, therefore, to know the ftars. But there are a hundred nebulæ which have fome refemblance to fmall comets. Thofe who with to diftinguifh them muft have recourfe to the Celeftial Atlas*, where they are all marked. This fudy will neither be long nor difficult. The Atlas of Berlin is much more complete: we thall give an account of it hereafter.

The night-telefope employed by Meffier, and with which he has already found twenty comets, is two feet in length, and has an aperture of $2_{\frac{1}{2}}^{\frac{x}{2}}$ inches: it has three eye-glaffes. The firft next the eye has a focus of $2 \frac{1}{2}$ inches, and ro lines of aperture; the fecond 9 , and the third $9 \frac{1}{\mp}$ inches. There are ro lines between the two, and 5 inches between the pre-

* A Paris, chez Lamarche, rue du Foin.

ceding 
ceding and the fecond. There is a diaphragm of 14 lines between the firft and the fecond eye-glafs, at the diftance of 2 inches from the former, and 3 from the fecond. This telefcope magnifies only five times, but it has a field of four degrees. One of the fame kind may be conftructed for $7^{\circ}$ or 80 francs.

B!urckhardt alfo has calculated the orbits of the comets of 1763,1771 , and 1773 ; and for the fecond he has found a hyperbolic orbit.

The comet which Meffier difcovered on the $14^{\text {th }}$ of June 1770, refpecting which Burckhardt made long and learned calculations, feems to have a fmall circular orbit of five years feven months. However, this comet was not feen before 1770, nor has it appeared fince. This can be afcribed only to great changes in its orbit.

Muft we then, after having afferted, in the 18 th century, that all the comets return, affert in the Igth that comets do not return, that of 1759 excepted?

On this account I no longer think but of comets; I fpeak of nothing but comets; and the only thing I recommend to my correfpondents is to fearch for them, as I write to them that the only thing wanting to aftronomy is the knowledge of thefe bodies.

On the $5_{5}$ th of May I had the pleafure of receiving the firt copy of my Hiftoire Celefte Françoife, the fruit of twelve years labour, which terminates the $50,000 \mathrm{ftars}$, on which my nephew Michel Lefrançois has employed the beft part of his youth. It contains alfo obfervations made by D'Agelet before he fet out on his voyage round the world; and thofe by which Darquier, aged 83 years, terminated his glorious aftronomical career.

The obfervations of Tycho, Flamfteed, Picard, Lacaille, and Mafkelyne, have been the foundation of all the progrefs made in aftronomy. The moft profound theories and the moft learned calculations cannot do without them, and cannot difpute with them in regard to importance or duration. Obfervations alone will furvive us; and obfervers, whom mankind too often affect to undervalue, may confole themfelves, that they will be the only aftronomers to whom, long after their death, the praifes and gratitude of our fucceffors and of pofterity will be addreffed.

Lefrançois Lalande, my nephew, continues his obfervations, together with the calculation of 3000 declinations and 1000 right afcenfions of the principal ftars, each obferved feveral times. Thefe long and painful labours have obtained for this able obferver a place in the National Inftitute. On 
the 26 th of December madame Lefrançois Lalande continured the reduction of the 50,000 ftars; an immenfe labour, to which the has devoted herfelf with courage, and which her pregnancy even has not interrupted. Their fon is preparing to tread in their fteps, and already ealculates with fome fuccefs. I hope that Ifaac Lalande will be the third aftronomer of his name.

Delambre has obferved feveral declinations with the multiplying circle. Piazzi has announced to us a catalogue of 7co ftars, which he obferved at Palermo; and Cagnoli is preparing a catalogue of 500 ftars, which he obferved at Paris and Verona with particular care.

Vidal, whofe courage and exactnefs $I$ have fo often celebrated, has fent me the continuation of the auftral Atars, which are not welk feen at Paris; the circum-polar ftars. which were wanting, and a very fingular triduum. On the 23d of Aprit and the following days he obferved all the planets every day. He has joined to them obfervations of Mercury and the fun at the two folftices with an ingenious compafs, which he employed to make a great number of obfervations on the declination of the magnetic needle.

Bourg, an aftronomer of Vienna, who gained the prize propofed by the Inftitute on the inequalities of the muon, continues to employ himfelf on that fubject. He has recalculated, with 3000 obfervations, the 24 inequalities of the moon; and has added new ones, which were pointed out to him by Laplace according to his theory. Thefe tables arrived on the 8th of December; the errors do not amount to $15^{\prime \prime}$; and the prize of 6000 franes, propoled by the Board of Longitude to the firft who fhould make good lunar tables, will be well merited by this able and courageous aftronomer. The Board of Longitude is ftill employed in verifying them; but all the obfervations lately made at Gotha confirm the exactnefs of thefe tables. For it was at the obfervatory of Gotha, the fanctuary of aftronomy in Germany, that M. Bourg finithed his labour. Baron von Zach had invited him thither, that be might enjoy all the comforts and conveniences he could defire.

What remains to be done in regard to the theory of the moon depends, perhaps, on fome terms in which the higher powers of the eccentricities and forces mut be employed. Burckhardt is now engaged in refearches an that fubject.

Arabian obfervations of the roth century had been employed for the motions of the moon. The manufcript which $I$ fortunately found among the papers of Jofeph Delifle made us defirous of obtaining he original, which was at Leyden; 
and the Batavian minifter fent it to us. C. Cauffin examined this manufcript : but it is not complete; it contains only obfervations already known. We found in it none of the information fo much withed for refpecting the inftruments of the Arabians, and their method of obferving; but it has furnithed us with fome interefting corrections for our copy, which is now printing in Arabic and French at the printing-office of the Republic by order of the minifter of the interior. The obfervations of the fummer folftice have again affured to us that the obliquity of the ecliptic is $23^{\circ} 28^{\prime} 6_{\frac{1}{2}}^{\prime \prime}$, being $5^{\prime \prime}$ more than in my tables. The multiplying circles give us the truth within a fecond; and I think we can with certainty fay that the diminution, which has occafioned fo muck difpute, is $33^{\prime \prime}$ per century; very far from that which C. Caffini affigned from bad obfervations made at the obfefvatory with bad inftruments.

The winter folftice gives us $8^{\prime \prime}$ lefs; but there is reafon to believe that this arifes from the refraction, which is not yet well enough known for fmall altitudes. Though the obliquity is nearly decided, the Academy of Berlin has ftill propofed this variation as the fubject of a prize for the year I802. It requires the moft interefting refearches and explanations in regard to this fubject, where feveral points ftill remain to be cleared up.

All the planets have been eclipfed by the moon in the courfe of this year, as has been obferved by Reggio in the Ephemerides of Milan. This phænomenon is rare. We were not able to make a good obfervation but of the eclipfe of Venus on the $1^{\text {th }}$ of May. We were, however, indemnified by the eclipies of that beautiful ftar the Virgin's Spike, obferved in many places on the 3 oth of March and the 24th of May, which enabled me to verify the longitudes of feveral countries. Eclipfes of four ftars of the firft magnitude are phænomena of very great importance for all determinations of this kind.

I have continued to difcharge the tafk, which I impofed upon myfelf forty years ago, of calculating all the eclipfes of the fun and ftars hitherto obferved, and from which aftronomers had neglected to draw conclufions on account of the length of the calculations. I have corrected the longitudes of Rome and Middlebourg, and of the new city of Wafhington in America.

M. Leduc of Sermonetta, Gäetani, and Conti have fent me obfervations from Rome. M. Ciccolini has fent me fome from Florence; and the day on which the king of Etruria came to the Inftitute, I had the pleafure of prefenting $\mathrm{H}_{3}$ 
to him a determination of the longitude of Florence, which had been very badly determined, notwithftanding the celebrity of that capital, and the great number of eminent men it has produced.

M. Kautfch, a piarift of Leutomifchel in Bohemia, has finithed an immenfe labour on the eclipfes of the fun. He has calculated, for the whole of the 19th century, charts in which are feen all the circumftances of thefe eclipfes for every country of the earth where they are vifible, in the fame manner as they have been inferted in our Ephemerides fince 1750 , and at prefent in the Connoiffance des Temps by the care of C. Duvaucel. I withed to have the means of publifhing the labour of M. Kautfch, whofe zeal and ability deferve every praife.

C. Goudin has alfo publithed an analytical method for eclipfes : he has applied it to the eclipfe of 1847 , which will be the moft confiderable of this century, and has calculated all its circumftances for the whole furface of the earth.

The conjunctions of the planets are not interefting to aftronomers, but they afford a fpectacle to the public, efpecially when connected with other events. Meffier, therefore, remarked, that when the cannon announced to us the happinefs of peace on the 3 d of October, the Moon, Venus, Jupiter, and Saturn, were near that beautiful far in the Lion's heart.

We no longer live in times when fuch phænomena are confidered as of importance, but in 1186 the aftronomers announced terrible revolutions in confequence of the conjunction of all the planets. I engaged C. Flauguergues to calculate this phænomenon exactly by our new tables, and he has found that on the $15^{\text {th }}$ of September at 5 h. $2 \mathrm{~m}$. all the planets were between 6 figns, and 6 figns io degrees of longitude.

Thefe are not complete conjunctions; exact conjunctions of all the planets are incalculable; a f ketch of thefe returns, in which I employed only days for the -duration of the revolutions, gave me 17 millions of millions of years as the interval between one conjunction and another. What would the cafe have been, had I taken into account the hours and minutes?

As the tables of Mars were the moft incorrect, C. Lefrançois has been employed on them fix months; he has calculated all the obfervations, and has employed all the new perturbations. He has carried his precifion to tenths of feconds, and has at length conftrueted tables of Mars, which will leave very little to be wifhed for, and which have 
appeared in the Connoiffance des Temps for the year 12 . have feen, with pleafure, my immediate fucceffor and deareft pupil purfue the labour which my mafter Lemonnier made me undertake, fifty years ago, in imitation of Tycho Brahe, who began his refearches on the planet Mars, and who put Kepler in the way of making his difcoveries by means of the fame planet. He will foon employ himfelf on tables of Venus, taking into account her perturbations.

For Saturn, the error has been found $+\mathrm{I}^{\prime \prime}$ in longitude and - $9^{\prime \prime}$ in latitude. Delambre has made new refearches to correct the error of $30^{\prime \prime}$ in the tables of Jupiter, but it has been found in the obfervations made for 60 years: we muft therefore fearch for the caufe of it in the theory, and in fome new irregularities.

Bouvard has terminated his calculations of all the perturbations of the planets, each by the action of all the reft, according to the theory of Laplace. The refult will be new tables, which will be ftill more correct.

C. Burckhardt has made an analytical and numerical calculation of the terms of the fifth order, which were not before taken into account in confequence of the length of the calculations. He has found that thefe terms increafe the great irregularity of Saturn by one minute.

C. Chabrol has calculated obfervations of the fun, and has found that $7^{\prime \prime}$ mut be deducted from the longitudes given by our tables. But Delambre has undertaken to calculate 7 or 800 obfervations of Bradley, applying 8 or Io new equations furnifhed by calculations of the attraction. The eccentricity of Jupiter and the earth give equations for the fun which amount to from 8 to $9^{\prime \prime}$. We fhall therefore foon have new tables of the fun ftill more correct than thofe publithed by Delambre ten years ago, and to which it ap. peared that nothing could be added.

For mercury, the error in my tables did not exceed 10 ". An obfervation of Venus on the 24th of May gave me an error in the tables of $+30^{\prime \prime}$. This feems to indicate that we ought to dedict $12^{\prime \prime}$ from the epoch, but that the equation of the orbit is good.

The Connoiffance des Temps for the year 12 (1804), which has juft appeared, contains every thing moft interefting that has occurred in regard to aftronomy during the laft year. Curious refearches refpecting the theory of the moon, by Laplace; new tables of Mars, by Lefrançois-Lalande; a new catalogue of ftars reduced, making the number I I, 300, being a continuation of thofe in the preceding volumes; important obfervations, tables, and calculations, by $\mathrm{Me}-$ $\mathrm{H}_{4}$ chain, 
chain, Delambre, Chabrol, Vidal, Thulis, Flauguergues, Ciccolini, Duc Lachapelle, Burckhardt, Bernier, Humboldt, Quenot, and feveral calculations by myfelf; with a notice of the moft important works that have appeared in the courfe of a year.

The Ephemerides of Vienna for $\mathrm{I} 802$ contain a fourth feries of longitudes determined by Triefnecker, who has calculated all the eclipfes of the fun and ftars which have been obferved; a confiderable and important labour, which remained to be undertaken. M. Triefnecker has given us at the fame time a table of all the preceding refults in regard to the pofition of towns where eclipfes have been obferved.

The third volume of the Memoirs of the Inftitute, the eighth volume of the Memoirs of the Italian Society, the Ephemerides of Berlin for 1803 and 1804 , thofe of Milan for 1801 , and the Journal of Baron von Zach during the whole year, have continued to furnith interefting oblervations and new memoirs. Baron von Zach has procured the obfervations made by Liefganig at Vienna from the year 1755 to 1774 ; and thofe which Niebuhr made in the Levant in $176 \mathrm{I}$, and which he did not publiph. We have received the Memoirs of the Academy of Berlin for 1796 and 1797, and the fixth volume of the Memoirs of Turin: but they contain nothing on aitronomy.

The obfervatory of Paris, having acquired new inftuments, has been put into activity by Mechain and Bouvard; and the Board of Longitude intends to print the obfervations of $180 \mathrm{r}$ in the fame form as thofe of Greenwich.

Caroche having finifhed the telefcope of 22 feet, Tremel is employed in conftucting a ftand to fupport it; and the platform on which it is to be placed is already in a ftate of great forwardnefs. On all occafions we have enjoyed the happinefs of having for minifter a man long celebrated by his attachment to the fciences, and who, in order to be ufeful to them, wanted only that influence of which he is fo worthy.

The tranfit telefcope which Jofeph Deline had, in $174^{8}$, erected at the hotel de Clugny, and with which $I$ as well as Meffier made my firft obfervations, had become almoft ufelefs by ruft. The Board of Longitude withed that it thould be reconftructed with platina, and our colleague Meffier will have new affiftance for his ufeful obfervations.

Lenoir has fhown at Paris, during the public exhibition of the year 9, that the French induftry is not inferior to the Englifh; he received from government one of the twelve gold medals diftributed to the molt meritorious of our artifts. 
The Board of Longitude has fent a quadrant to Flanguergues at Viviers, and one to Dangos at Tarbe, to enable them to make more correct and more continued obfervations.

Flauguergues has already employed his obfervations to determine the latitude of his obfervatory $44^{\circ} 29^{\prime} 22^{\prime \prime}$, greater by $18^{\prime \prime}$ than what was given by the triangles; he has affiduoufly continued to obferve the eclipfes of Jupiter's fatellites; he has obferved the fpots of the fun, which were frequent this year, and has calculated a great many pofitions of the ftars.

Chabrol has communicated to us a new analytical method for eclipfes, and has calculated feveral; he has alfo verified the tables of Mars and Mercury by obfervations in the prefent year. He has reduced 600 obfervations of the ftars, and has calculated 600 longitudes in the fundamental catalogue: in a word, he fhows himfelf a young zealous co-operater, curious and void of ambition, who is entitled to our grateful acknowledgments.

C. Mougin, curé of $\mathrm{La}$ Grande-Combe-des-Bois, in the mountains of the department of Doubs, has fent us a large table of preceffions; that is to fay, of the annual changes of the ftars in right afcenfion, according to the data with which I furnithed him. For thirty years paft we have received from this worthy paftor marks of zeal, application, curiofity, and courage, very rare, efpecially in the deferts.

Dr. Mankelyne has fent us his obfervations of 1800 , a continuation of the valuable collection he has been making for 36 years; and he has announced to us the Nautical Almanac of 1806 .

[To be concluded in our next.]

XXIV. Some Account of the Poifonous and Injurious Honey of North America. By Benjamin Smith Barton, M. D.*

$\mathrm{I}_{\mathrm{N}}$

$\mathrm{N}$ the year I 785 I had an opportunity of obferving fome of the difagreable effects of our wild honey upon feveral perfons who had eaten of it, in the weftern parts of Pennfylvania, near the river Ohio. From thefe effeets I was perfuaded, that a fubftance which is generally confidered as entirely innocent, is capable of doing much injury to the conftitution. I was, therefore, induced to pay fome

* Read before the American Philofophical Society, and communicated to the Editor of the Philo ophical Magazine by the author. It will form part of the fifth volume of the American Tranfactions. 